\title{
Central Office of Press Control/ Main Control Office of Press, Publication and Performances - background, audit scope and staff
}

The Main Control Office of Press, Publication and Performances was originally under the name of the Central Office of Press Control (hereinafter: the COPC) by the order of the minister of public security - Stanisław Radkiewicz, on 19 January 1945 in Warsaw. The COCP was subject to the Ministry of Public Security. After the fall of the Warsaw Uprising, on 3 November 1944, based on the order of Nikolai Bułganin, the representative of the Soviet Government in PKWN, two so-called Soviet advisers came to Poland, the officers of the Soviet GŁAWLIT (the Main Office of Protection of State Secret and Press) - Piotr Gładin and Kazimierz Jarmuż, who had to organise the institution of censorship based on the Soviet model ${ }^{1}$. Jakub Berman told about the Soviet consultants in an interview with Teresa Torańska, he called them "quite cunning and shrewd, after all, they were from the security forces, sensitive to any kind of frauds [made by the Polish Communists]". ${ }^{2}$ In turn, Józef Światło said, in an interview with Zbigniew Błażyński, they were assigned - in the context of the creation of the office of security, but it can be assumed that a similar situation took place in the structures of propaganda and censorship - "to all the major resorts (sometimes even at the provincial levels)". ${ }^{3}$

\footnotetext{
* Dr, e-mail: ka.kaminska@uw.edu.pl, Uniwersytet Warszawski, Wydział Dziennikarstwa, Informacji i Bibliologii, ul. Bednarska 2/4, 00-310 Warszawa.

${ }^{1}$ T.M. Goriajeva, Blickrig v Polszu, in: Iskljuczit' wsiakije upominanija... Oczerki istorii sovietskoj cenzury, Moscow 1995, pp. 108-111.

${ }^{2}$ T. Torańska, Oni, Warsaw 1990, p. 75.

${ }^{3}$ Z. Błażyński, Mówi Józef Światto: Za kulisami bezpieki i partii 1944-1955, Warsaw 2003, p. 10.
} 


\section{Soviet advisers from GLAWLIT}

After the meeting with Jakub Berman, on 5 January 1945, agents were recruited to the Press Control Offices. Berman came out with a proposal to appoint as a director of the institution, an employee of the Polish Embassy in Moscow, who would watch over the proper line of ideology of a new facility, but eventually it was decided that the function would be taken by Leon Rzendowski, a member of PPR; before the war, he was an engineer agronomist, without experience in the work of the censorship, who was charged with the organization of the institution under the supervision of Soviet advisers of GŁAWLIT. Rzendowski, at the time of the nomination, was the chief of the department of agriculture at PKWN ${ }^{4}$. In the COPC, a chief and three censors worked. Since 20 January 1945, all central Polish newspapers began to be controlled. At the turn of February and March 1945, GŁAWLIT employees reported in the headquarters about significant merits of "a young Polish censorship, which without looking at the deficiencies and not enough experienced, implemented Bolshevik style of work, of fraternal Soviet censorship"s.

Censors from the Military Censorship of the HQ of the Polish Army were delegated to work in the $\mathrm{COCP}^{6}$. The COCP was to serve the party management of PPR. The establishment was not publicly announced.

The COCP was not the only office responsible for the censorship and propaganda at that time. It is worth mentioning that the law on the establishment of the Polish Committee of National Liberation of 21 July 1944, established the Resort of Information and Propaganda, which was liquidated in 1947. The tasks of the resort were the issues of daily papers, periodical publications, press agencies, information and telegraph, radio, film production and cinematography, issues of informative publications and propaganda as well as mass propaganda in the country and abroad, and "other issues unless they are dedicated to the scope of activities of other resorts". In practice, the competence of MIiP covered with the scope of the activities of a number of other resorts and institutions, inter alia the Resort of Art and Culture, the Resort of Education and CBKP/GUKPPiW.

By the power of digression, one should also mention that the structure of the Resort of Public Security (since 1 December 1944 MPS) included the Censorship Department established on 1 September 1944, which dealt with the censorship of correspondence, though PKWN issued a decree to introduce the war censor-

\footnotetext{
${ }^{4}$ At the same time, established on 18 July 944, Resort of Information and Propaganda, created during a meeting of the Management Board of the Union of the Polish Patriots and delegates from National Council, M. Ciećwierz, Polityka prasowa 1944-1948, Warsaw 1989, p. 31. See also: Pierwszy cenzor Polski Ludowej, „Rzeczpospolita” 1994, 16-17 VII.

${ }^{5}$ T.M. Goriajeva, Blickrig v Polszu..., p. 291.

${ }^{6}$ Główny Urząd Kontroli Prasy 1945-1949, oprac. D. Nałęcz, Warsaw 1994, p. 27.
} 
ship on 28 December 1944. On 15 January 1946, the Censorship Department was transformed into the Main Censorship Office, and then on 2 December 1946, the correspondence per-lustration was taken by B Office, and since 15 December 1947, VII Office of II Department ${ }^{7}$.

Although the COCP was established in January, is its field facilities started operations, due to organizational and technical reasons, a few weeks later. E.g. WBKP in Kielce started operation on 9 March 1945, in Kraków on 16 February, in Rzeszów on 1 April.

\section{Recruitment process}

Until 15 November 1945 (then was transformed into GUKPPiW), the COCP was subjected to the minister of public safety, Stanisław Radkiewicz, therefore, the natural source of recruitment involved officers of the Security Office, who, as stated by Piotr Kołakowski in the monograph devoted to the activities of NKVD and GRU on the Polish land during World War II, were recruited from three sources: intelligence and subversive groups trained by NKVD, the Polish Army in the Soviet Union and members of the People's Army. The decisive role in the security structures was played by people trained in the Soviet Union, particularly during the courses in Kuibyshev ${ }^{8}$. Since the beginning of the Resort of Public Security (the time of the transformation of PKWN in the Provisional Government, on 31 December 1944, one changed its name to the Ministry of Public Security) was under the strict control of the Soviet security authorities. Orders of the SO, as Kołakowski writes, were dependent on and closely linked to exposures of NKGB, NKVD and "Smersh" counterespionage. The Soviet delegates and advisers operated at every level of the Resort of Public Safety and had a decisive influence on all political and social issues. ${ }^{9}$

SO officers were not suitable to operate in such a specific industry. They were recruited from the lowest levels of the society. The security unit involved usually bandits who previously often collaborated in Germany. Their qualifications to work in the Security raised doubts even of Radkiewicz. ${ }^{10}$

Objections to the censors recruited from the $\mathrm{SO}$ were raised by the chief of WBKP in Łódź during the briefing in June 1945. "Practice shows that censorship must be installed by the headquarters and province directly, and not to take people

${ }^{7}$ G. Majchrzak, „Wojenna” cenzura, „Biuletyn Instytutu Pamięci Narodowej” 2004, no 2, p. 50. See also: Aparat bezpieczeństwa w Polsce. Kadra kierownicza 1944-1956, vol. I, ed. by K. Szwagrzyk, Warsaw 2005, p. 30.

${ }^{8}$ P. Kołakowski, NKWD $i$ GRU na ziemiach polskich 1939-1945, Warsaw 2002, p. 277.

${ }^{9}$ Ibid., p. 283.

${ }^{10}$ Ibid., p. 284. 
from the Safety. Hence, the conclusion is that, in my opinion, we should recruit people with higher education from the office. Good will is not enough here, a man must represent a high level". ${ }^{11}$ The quoted chief was forced, about which he also spoke during the briefing, to dismiss a significant group: "We were forced to change $50 \%$ of the censorship unit in a month. These people we sent to the $\mathrm{SO}$, and we recruited people of the Democratic Party and the Writers Association. In this way, instead of people ruthlessly honest and dedicated, we received people with higher education". ${ }^{12}$

\section{No people willing to work in the censorship}

A major problem influencing on the operation of provincial, municipal and county Control Offices of Press was the lack of people willing to practice as a censor. The directors of provincial control offices addressed this problem to PPR, but, according to the words of one of the chiefs "[...] those recommended were mostly young high school students, and even a woman, who has been a censor before the war, applied". "We have no-one to rely on in the counties and municipal offices, said during the briefing in 1948 the director of one of the provincial control office, because people are captured by the ministries, political parties, industry. People go there, because it is a financial promotion for them". ${ }^{14}$

Censors went to the COCP themselves (e.g. based on recommendations), or had previously worked in the structures of information and propaganda, from where they moved to newly created offices of censorship. One of the censors, mentioning its origins, wrote that before the war it had met "[...] on the road of life, communists. It understood the great truth of socialism", "the ideology of the communist party became the gospel for it". "At the same time, it began operating with its father, who was a member of PPR during the occupation, and a brother, an employee of the SO after the liberation" - described its story in the Bulletin of Information and Instructions, an internal document of censors. ${ }^{15}$

The first censors were captured according to the following criteria: acceptance of post-Yalta reality, willingness to work, reading skills, relative knowledge of literature and the Polish press.

If the above criteria were met, age was not important. One of female censor mentioned that she had become a censor at the age of 17, and while working in the

${ }^{11}$ Główny Urząd Kontroli Prasy 1945-1949..., p. 62.

${ }^{12}$ Ibid.

${ }^{13}$ AAN, GUKPPiW, Sekretariat Prezesa. Odprawy krajowe 4-5.06.1948, Ref. No. 421, vol. III, p. 47.

14 Ibid., p. 49.

${ }^{15}$ AAN, GUKPPiW, Biuletyn Informacyjno-Instruktażowy 1955, No 1 (37), p. 1-2, Ref. No. 420. 
office, she graduated and got to college (to be more precisely, the Evening University of Marxism-Leninism). Another of female censor, by mentioning in 1955 her beginnings in the profession, wrote: "[...] we, young people, like me, who came to the office at the age of 20, we have every right and duty to say that the office grew us up. The Office, i.e. people working there, people bound by love and enthusiasm to our thankless, tedious and inefficient work". ${ }^{16}$

A breakthrough in the selection of personnel occurred in 1948. One began to deeply analyse CVs of censors admitted to work. The Director of GUKPPiW, Antoni Bida, said in 1949, during the national briefing, that the current employees selection was unreliable. "If CVs were reviewed, Bida claimed, that was rather a formality. They were rarely checked. [...] I note that this does not mean the introduction of the atmosphere of man-hunting or mistrust. That would be harmful. But you just have to know who to work with and do it discreetly and robustly". ${ }^{17}$

Newly hired employees, during a number of years of work in censorship, were provided with various trainings to improve professional and ideological qualifications. They began studying at the Central School of Planning and Statistics, since 1952, on the Evening University of Marxism-Leninism, some, e.g. from the financial departments, were provided with the Higher Courses Accounting of Budget at the Presidium of the Council of Ministers.

Although self-study lasted for quite a long time, there are examples showing that, in the Main Office of Press, Publications and Performances, one could develop its career and be promoted from the position of a cleaner to an overseer of the Secret Registry or a political censor par excellence, which confirms the assertion, how much manpower was not enough in the post-war period. ${ }^{18}$

\section{Establishment of GUKPPiW}

On 15 November 1945, the COCP was transformed by the resolution of the Council of Ministers into the Main Office of Control of Press, Publications and Performances and was subjected to supervision by the Presidium of the Council of Ministers (although in practice it was still subject to Jakub Berman, who, at the same time, was responsible for MBP). ${ }^{19}$ Exclusion of GUKPPiW from MBP and the affiliation at the Presidium of the Council of Ministers was to offset security offices from significant influence on the most important press decisions. The changed position of the office was also to prevent from associating GUKPPiW with terror.

\footnotetext{
${ }^{16}$ Ibid., p. 14.

${ }^{17}$ Ibid., p. 89.

${ }^{18}$ AAN, GUKPPiW, Biuletyn Informacyjno-Instruktażowy 1955, No 1 (37), p. 52, Ref. No. 420.

${ }^{19}$ Główny Urząd Kontroli Prasy 1945-1949..., p. 17.
} 
Tadeusz Zabłudowski was appointed as the Director of GUKPPiW. He was a pre-war communist, sent to the post by PPR, when leaving the position of the chief editor of "Głos Ludu", a press unit of PPR.

The legal frame was provided for censorship by the Decree of 5 July 1946, signed by the President of the National Council of Bolesław Bierut and the Prime Minister Edward Osóbka Morawski. The decree was repealed on 31 July 1981, after the adoption by the Parliament of the Law the act on the control of publications and performances.

The whole decree covered half a page of a manuscript. The tasks of GUKPPiW were formed rather imprecisely and vaguely, which left officials considerable space for free interpretation of individual records.

The tasks of GUKPPiW included supervision over press, publications and performances in order to prevent from:

a) threatening the political system of the Polish State,

b) disclosure of state secrets,

c) violation of the international relations of the Polish State,

d) violation of the law and good manners,

e) misleading the public by providing messages incompatible with reality. ${ }^{20}$

The general records of the act provided the possibility of any interpretation, particularly in the case of the last paragraph. Although the decree did not imply that GUKPPiW would be responsible for granting concessions for the issuance of press, in practice this operation came within the scope of the tasks of the office. The decree had no real importance towards the implemented rules of establishing and complying with the law by the communists. From the point of view of an average censor, ideological trainings and instructional publications, determining whether the material threatens the interests of the state, which were used in a daily work, had more important meaning than the legal basis for the activities of the office. A major role is also played by intuition and political knowledge as well as insight allowing to independently determine the content of "reactionary and hostile, under the old categories of thinking about the new reality". ${ }^{21}$

The control covered: magazines, brochures, books, libraries, theatres, cinemas, radio networks, exhibitions, museums, printing houses, and exactly the same entities that had been controlled by MIiP. The contacts between the control offices of press and other ministries responsible for information, art and education were not always correct. For example, in Kielce, the chief of WBKP, during the briefing in 1945, stated that contacts between WBKP, the Ministry of Culture and Art and the Ministry of Information and Propaganda were cool: "Hostility to-

\footnotetext{
${ }^{20}$ Dz.U. 1946 No 34, issue 210.

${ }^{21}$ AAN, GUKPPiW, Sekretariat Prezesa. Odprawy krajowe 2-25.05.1945, Ref. No. 421, issue I, p. 8.
} 
wards us from these offices revealed in slandering us in private conversations". ${ }^{22}$ In addition, the Ministry of Culture and Art, without consultation with the office, issued permits for "[...] extremely pornographic or chauvinistic performances". ${ }^{23}$ Cooperation with the Ministry of Culture and Art also included preventive monitoring of libraries. WBK in Kielce appointed a committee, which included representatives of art and culture, information and propaganda, the Management Board of Education, representatives of the Public Library and the representative of the control office at the local level. In some counties, the commission consisted of representatives of PPR, PPS, SD or SL. The books "of an antidemocratic na-ture" were withdrawn from libraries. ${ }^{24}$

In turn, the Ministry of Public Security, at which the COCP was affiliated, usually assisted the employees of the and organisational issues, e.g. arranging offices, by providing radios and weapons (the employees controlled distant sites at night, and a number of them had not even bicycles). Although, the scale of this assistance varied depending on the region.

Although Manifesto of PKWN guaranteed the citizens freedom of press, at the same time, it stated that civil liberties could not serve the enemies of democracy. It was officially declared, as persuaded by Jakub Berman, during the congress of delegates from provinces and municipal control offices in May 1945, that "[...] we want to have free press, independent press, press denouncing the opening views, but press with pure intentions", it de facto had to become a tool in the hands of political decision makers. Already in "Lublin" Poland, the foundations for the Soviet model of press control were laid, which according to W. I. Lenin, should be "collective agitator, organizer and educator". According to Andrzej Paczkowski, a smooth transition from the post-war relative pluralism of press to the second stage, so the Stalinist period, indicates that it was not a revolution, but evolution. In the first years after the takeover of power by the communists, the press system was characterized by some degree of pluralism. Some PSL papers were published, the Jewish press existed, in which not all papers accepted the communist policy, the Catholic Church and the Catholic environments had their own press, while PPR wanted even then to create the impression of the independence of press on it, the best example of which was Borejsza and his great project - Cooperative Publishing "Czytelnik". ${ }^{25}$

${ }^{22}$ AAN, GUKPPiW, Sekretariat Prezesa. Odprawy krajowe 2-25.05.1945, Ref. No 421, vol. I, p. 21.

${ }^{23}$ Ibid., p. 22.

${ }^{24}$ Ibid.

25 J. Perkal (A. Paczkowski), Polityczna historia prasy w Polsce 1944-1984, in: 40 lat władzy komunistycznej w Polsce, London 1986, p. 158. 


\section{Bibliography}

AAN, GUKPPiW, Biuletyn Informacyjno-Instruktażowy 1955, nr 1 (37), s. 1-2, sygn. 420.

AAN, GUKPPiW, Sekretariat Prezesa. Odprawy krajowe 2-25.05.1945, sygn. 421, tom I.

AAN, GUKPPiW, Sekretariat Prezesa. Odprawy krajowe 4-5.06.1948, sygn. 421, to III.

Dz.U 1944, nr 4, poz. 20.

Dz.U. 1946 nr 34, poz. 210.

Aparat bezpieczeństwa w Polsce. Kadra kierownicza 1944-1956, t. I, red. Szwagrzyk Krzysztof,

Warszawa 2005.

Błażyński Zbigniew, Mówi Józef Światto: Za kulisami bezpieki i partii 1944-1955, Warszawa 2003.

Cenzura w PRL. Relacje historyków, oprac. Romek Zbigniew, Warszawa 2000.

Ciećwierz Mieczysław, Polityka prasowa 1944-1948, Warszawa 1989.

Główny Urząd Kontroli Prasy 1945-1949, oprac. Nałęcz Daria, Warszawa 1994.

Perkal Jakub (Paczkowski Andrzej), Polityczna historia prasy w Polsce 1944-1984, w: 40 lat władzy komunistycznej w Polsce, Londyn 1986.

Kersten Krystyna, Nie ma wolności dla reakcjonistów (cenzura w PRL), w: Kersten Krystyna, Pisma rozproszone, oprac. Szarota Tomasz, Libionka Dariusz, Toruń 2005, s. 400.

Kołakowski Piotr, NKWD i GRU na ziemiach polskich 1939-1945, Warszawa 2002.

Majchrzak Grzegorz, „Wojenna” cenzura, „Biuletyn Instytutu Pamięci Narodowej” 2004, nr 2, s. 50.

Pierwszy cenzor Polski Ludowej, wywiad z Leonem Rzendowskim przeprowadzony przez Konrada Zaborskiego, „Rzeczpospolita” 1994, 16-17 VII.

Torańska Teresa, Oni, Warszawa 1990.

Goriajeva T.M., Blickrig v Polszu, w: Iskljuczit' wsiakije upominanija... Oczerki istorii sovietskoj cenzury, Moskwa 1995.

Kamila Kamińska-Chełmniak

Central Office of Press Control/ Main Control Office of Press, Publication and Performances - background, audit scope and staff

\section{(Summary)}

The aim of the article was to present the circumstances of the establishment and the scope of activities of the Central Office for Control of the Press, which was transformed into Main Office for Control of the Press, Publications, and Public Performances in November 1945. The article is an attempt at answering the following questions: who were the first censors? From what communities/professional groups did they come? According to what criteria were the censors selected shortly after the founding of the Center? How did the so-called Soviet advisors influence the process of the emergence of institutional censorship in the Polish territory during World War II?

Keywords: Central Office of Press Control, Main Control Office of Press, Publication and Performances; GŁAWLIT; Censorship in PRL 